\title{
Literasi Media Sosial dalam Pemasyarakatan Sikap Moderasi Beragama
}

\author{
Social Media Literacy \\ on Socializing Religous Moderate Action
}

\author{
Engkos Kosasih \\ Pascasarjana UIN Sunan Gunung Djati Bandung \\ Email: ekosasih72@gmail.com
}

Artikel diterima 15 Oktober 2019, diseleksi 30 November 2019, dan disetujui 10 Desember 2019

Abstrak: Media sosial saat ini berhasil membentuk kekuatan besar dalam membentuk perilaku manusia dalam kehidupan modern yang dinamis ini. Belakangan ini, media sosial merupakan fenomena baru yang sangat digandrungi masyarakat modern tanpa mengenal usia dan afiliasi sosial apapun. Alihalih menggunakan untuk hiburan semata, tapi menjadi bumerang bagi diri sendiri. Masyarakat perlu mengetahui dibalik kebebasan media sebagai alat ekspresi diri dalam berpendapat, tetap ada berbagai ranah aturan serta etika yang harus dipenuhi. Dengan demikian pengguna medsos harus bersikap adil (tidak berlebihan) dalam menyikapi berbagai hal yang didapatkan, jangan sampai sikap keberpihakan terhadap sesuatu membuat kita terjebak dalam lubang kemadharatan dari medsos. Hadirnya tulisan ini diharapkan ada sikap yang berbeda dari para pengguna medsos, yaitu berfikir dan bersikap moderat terhadap hal-hal yang beredar di medsos, terutama moderat dalam hal beragama. Penelitian ini menggunakan metode kualitatif, yang mana data yang dibutuhkan hanya sebatas dokumen-dokumen yang dianalisis sesuai dengan kebutuhan penelitian. Hasil dari penelitian ini bahwa bagaimana caranya seseorang sebagai pengguna medsos harus bisa menerapkan sikap wasaty atau adil dalam mengambil segala yang ada di dalamnya. Masyarakat (user medsos) harus bisa memilah dan memilih apa yang seharusnya diterima dan apa yang seharusnya ditolak. Hal ini terlebih terhadap hal-hal yang berbau dengan 
masalah agama, seperti berbagai doktrin jelek yang tersebar melalui medsos. Dengan demikian, masyarakat harus bisa menyaring berbagai informasi yang masuk dan harus bersikap moderat terlebih dahulu terhadap berbagai informasi tersebut, sebelum pada akhirnya memutuskan untuk mengambil sikap.

Kata Kunci: Literasi, Moderasi, Media Sosial.

Abstract: Social media is currently successfully forming a great force in shaping human behavior in this dynamic modern life. Lately, social media is a new phenomenon that is loved by modern society without knowing any age and social affiliation. Instead of using it for entertainment, but backfire for yourself. Society needs to know behind the freedom of the media as a means of self-expression in opinion, there are still various domains of rules and ethics that must be met. Thus the user of social media must be fair (not excessive) in responding to various things that are obtained, do not let the attitude of partiality towards something makes us trapped in the pit of harm from the social media. The presence of this article is expected to have a different attitude from the users of social media, which is to think and be moderate about things that are circulating in the social media, especially moderate in matters of religion. This study uses qualitative methods, where the data needed is only limited to the documents analyzed in accordance with research needs. The results of this study that how a person as a social media user must be able to apply a attitude of fairness or fairness in taking everything in it. Society (user social media) must be able to sort out and choose what should be accepted and what should be rejected. This is especially true of matters related to religious matters, such as various bad doctrines spread through social media. Thus, the community must be able to filter the various information that comes in and must be moderate to the various information before finally deciding to take a stand.

Keywords: Literacy, Moderation, Social Media

\section{A. Pendahuluan}

Perkembangan ilmu pengetahuan dan teknologi hari ini tidak bisa dihindari dari kehidupan masyarakat, terutama dalam konteks 
masyarakat perkotaan dan juga bahkan bagi masyarakat pedesaan.Dulu mereka (masyarakat pedesaan) dikatakan masyarakat yang tertinggal dalam masalah teknologi dan informasi, untuk hari ini tidaklah demikian. Dalam konteks ini, kehadiran internet yang memudahkan masyarakat untuk mendapatkan segala bentuk informasi, baik dalam maupun luar negeri.

Internet merupakan sesuatu hal yang tidak asing bagi masyarakat modern Indonesia saat ini. Sebelumnya, internet hanya digunakan untuk bertukar informasi melalui e-mail, chatting dan untuk mencari informasi dengan menelusuri di mesin pencari google "browsing" dan "googling". ${ }^{1}$ Ada beberapa manfaat yang bisa dirasakan masyarakat dari adanya perkembangan teknologi, diantaranya dalam bidang pendidikan, telecenter bagi masyarakat, sebagai layanan e-commerce, bidang bisnis, bidang manajemen kesehatan, dan lain sebagainya. ${ }^{2}$

Bentuk dari perkembangan teknologi dan informasi saat ini bisa dilihat dan dirasakan dengan hadirnya beberapa media sosial, seperti facebook, instagram, twitter, whatsApp, telegram, dan lain sebagainya.Dengan demikian, keberadaan sosial media sangat penting untuk diperhatikan oleh masyarakat pada umumnya, baik itu dari segi manfaat atau dampak positif maupun dampak negatif yang ditimbulkannya.

Media Sosial memang sudah menjadi keniscayaan masyarakat modern saat ini. Namun di sisi lain, dampak medsos salah satunya seperti tersebarnya hoax. Hoax yang berkembang saat ini banyak disebabkan oleh hal-hal yang berafiliasi dengan politik, etnis, agama, dan golongan sehingga mengarah kepada kerumitan yang tinggi.Kondisi ini melahirkan bullshit, yaitu tidak adanya perhatian kepada kebenaran, suatu kondisi dimana emosi dan logika dianggap lebih penting daripada fakta dan bukti. Kebenaran itu tidak dianggap penting karena yang penting adalah justifikasi apa yang dianggap kebenaran. ${ }^{3}$

Melihat fakta di atas, mengenai kejahatan yang terjadi melalui media sosial berupa hoax timbul dari berbagai logika yang berupa argumentasi 
dan justifikasi yang kurang bahkan tidak baik dan bertentangan dengan fakta yang sebenarnya. Selain itu, hoax juga diakibatkan dari adanya kepentingan pribadi dan kelompok dengan mengatasnamakan politik, agama, etnis, dan golongan tertentu. Tentunya hal ini sangat bertentangan dengan prinsip agama Islam yang tidak menginginkan adanya kebohongan (hoax) yang tentunya akan merugikan diri sendiri dan orang lain.

Masyarakat Islam di manapun tentu menginginkan terwujudnya pribadi muslim yang baik, sehingga pada tahap selanjutnya bisa menciptakan tatanan masyarakat muslim yang cerdas dan paham terhadap berbagai esensi keyakinan beragamanya maupun sikap moralitasnya. Masyarakat tentunya harus mempelajari moralitas yang bertujuan untuk mengetahui mana yang baik dan mana yang buruk. ${ }^{4}$ Apalagi masyarakat Islam yang senantiasa memegang pedoman hidupnya (al-Qur'an dan Hadis) harus bisa membedakan antara yang baik dan buruk. Apabila sudah terwujud langkah seperti ini, maka akan dengan mudah menyebarkan pesan-pesan moderasi dan memberantas sikap-sikap eksterimitas dalam segala dimensi kehidupan, terutama dalam kehidupan beragama.

Pesan-pesan moderasi, terutama moderasi dalam beragama saat ini bisa dengan mudah disampaikan dengan adanya perkembangan teknologi dan informasi (sosmed).Akan tetapi hal itu harus disampaikan dengan tanpa adanya keberpihakan terhadap salah satu, baik perorangan ataupun kelompok. Apabila hal itu telah dilakukan, maka teknologi dan informasi melalui sosmedakan sangat membantu manusia dalam menjalankan ke-Islamannya secara baik dan benar sesuai dengan pedoman al-Qur'an dan Hadis. Dengan demikian, Islam bisa menjawab segala hal yang ada dalam kehidupan ini.

Keuniversalan Islam itu sangat erat kaitannya dengan salah satu karakteristik dakwah Islam yaitu sikap wasaty atau moderat, baik dalam ibadah maupun muamalah.Dalam kehidupan modern sekarang ini, 
kita dihadapkan pada beberapa persoalan yang kompleks dan rumit sebagai akibat dari derasnya arus informasi dan perubahan sosial yang diakibatkan dari kurang tepatnya penggunaan teknologi dan informasi. Tafsir agama seringkali gagap dalam menyikapi tantangan modern seperti itu.Ia kesulitan memberikan jawaban dari kompleksitas masalah sehingga akan mengganggu doktrin keuniversalan Islam jika tidak mampu menjawabnya, dan seolah Islam melalui doktrinnya memihak terhadap sesuatu. ${ }^{5}$

Hanya saja berbagai tantangan yang mendera sikap moderasi ini muncul baik dari dalam masyarakat Islam itu sendiri atau berbagai faktor eksternal lainnya.Ada fakta yang diinginkan kelompok tertentu yang berusaha mempersepsikan Islam jauh dari sikap moderasi sehingga melahirkan kesadaran menggunakan segala potensi dan kekuatan guna menjaga jati diri umat yang asli ini dari segala pengaburan misi asli yang sejati.

Riset terhadap peran jaringan medsos guna mengokohkan nilai-nilai keuniversalan Islam dinilai sangat urgen agar umat bisa beradaptasi dengan alat modern ini secara cerdas dan bertanggungjawab.Dakwah keagamaan dituntut mampu beradaptasi dengan perkembangan zaman yang selalu dinamis. Ini berarti memerlukan sikap yang tepat terhadap penggunaan medsos, sehingga pesan-pesan moderasi beragama akan mudah dimasyarakatkan dengan tepat dan baik. Tidak mungkin bangunan peradaban umat bisa berdiri kokoh pada saat ini tanpa adanya sikap positif dan smart menggunakan berbagai fasilitas komunikasi modern yang ada.

Teknologi bukannya harus dimusuhi tetapi harus dipergunakan dengan sebaik-baiknya, agar bisa melahirkan kemaslahatan umat secara merata.Islam dituntut untuk diterjemahkan ke dalam realita kehidupan modern dengan memiliki kemampuan akomodatif dan kompatibel yang tinggi dengan segala perubahan sosial masyarakat modern. ${ }^{6}$ 
Analisa sosial dalam tulisan ini ingin memetakan potensi dan kekuatan medsos dalam penyebaran sikap moderasi beragama di kalangan anggota masyarakat modern saat ini.Perkembangan teknologi komunikasi yang dahsyat pada saat ini perlu digunakan sebaik-baiknya guna menciptakan kemaslahatan bagi masyarakat, bukan kemadharatan atau kerusakan.Medsos memiliki tingkat akurasi dan penetrasi sosial yang tinggi sehingga harus menjadi kepedulian para cendekiawan umat untuk membahas dan menyelami fenomena ekstremisne yang justru lahir dari fasilitas medsos seperti ini.Para cendekiawan harus menyadari sejauh mana dampak sosial dari alat medsos ini dalam menciptakan identitas diri pemuda menuju sikap moderat dalam beragama. Tanpa kesadaran seperti ini, mustahil akan muncul sikap dewasa dari para pemuda dalam menggunakan fasilitas medsos yang justru banyak melahirkan efek negatif dari pada dampak positifnya.

Penelitian ini menggunakan metode kualitatif, salah satu ciri dari penelitian kualitatif yang diterapkan dalam penelitian ini adalah pengamatan, wawancara dan pengamatan dokumen. ${ }^{7}$ Salah satu ciri penelitian kualitatif yang penulis ambil dalam penelitian ini adalah dengan cara menghimpun beberapa sumber yang berkaitan dengan fokus masalah dan menelitinya. Teknik atau cara pengumpulan data yang dilakukan dalam penelitian ini dengan cara studi kepustakaan (library research) yang terfokus pada sumber-sumber tertulis saja. Setelah itu data yang sudah terkumpul dari berbagai sumber dianalisis sesuai dengan kebutuhan penelitian

\section{B. Hasil dan Pembahasan}

Ada beberapa pembahasan yang akan diuraikan dalam penelitian ini, setidaknya beberapa poin tersebut berkaitan dengan masalah dalam penelitian ini. Pembahasan tersebut setidaknya terbagi ke dalam tiga poin, pertama berbicara tentang media sosial, kedua tentang fikih media sosial dan yang terakhir berbicara tentang moderasi beragama yang ada kaitannya dengan penggunaan media sosial. 


\section{Pengertian Media Sosial (Medsos)}

Istilah media sosial disusun dengan dua kata yang mempunyai makna masing-masing, yaitu kata media dan kata sosial. Kata media bisa diartikan sebagai alat yang biasa digunakan untuk berkomunikasi, sedangkan sosial sebagai aksi (interaksi) yang dilakukan oleh individu yang akan memberikan kontribusi terhadap masyarakat sekitarnya. ${ }^{8}$

Media sosial (sering disalahtuliskan sebagai sosial media) adalah sebuah media daring, dengan para penggunanya bisa dengan mudah berpartisipasi, berbagi, dan menciptakan isi blog, jejaring sosial, wiki, forum dan dunia virtual.Blog, jejaring sosial dan wiki merupakan bentuk media sosial yang paling umum digunakan oleh masyarakat di seluruh dunia. ${ }^{9}$ Dengan kata lain, Media sosial adalah sebuah sarana interaksi sosial berbasisdaring (dalam jaringan) yang terhubung dengan jaringan internet, yang berfungsi memudahkan penggunanya untuk saling berbagi informasi atau cerita, berpartisipasi, melakukan komunikasi lewat berkirim pesan, menjalin relasi dan membuat jaringan. ${ }^{10}$

Anderas Kaplan dan Michael HaenLein mendefinisikan media sosial sebagai kelompok aplikasi berbasis internet yang membangun di atas dasar ideologi dan teknologi Web 2.0, dan yang memungkinkan penciptaan dan penukaran atau user generated content. ${ }^{11}$

Dari beberapa pengertian di atas, dapat ditarik sebuah kesimpulan bahwa media sosial mempunyai arti sebuah alat yang digunakan seseorang untuk berkomunikasi dengan orang lain dan komunikasi tersebut tentunya akan memberikan kontribusi terhadap lawan komunikasinya. Terlepas kontribusi itu baik atau buruk, karena interaksi seseorang tidak bisa dilepaskan dari dua hal tersebut (baik atau buruk).

Jaringan Medsos ini dipandang sebagai sarana komunikasi modern yang paling efektif dan efisien dengan daya pengaruh yang luas bagi para pemakainya.Ia kini menjadi alat atau media sangat populer yang bisa dipakai oleh siapapun dengan motivasi apapun juga, dengan syarat terhubung dengan jaringan internet. Berbagai elemen masyarakat bisa 
digerakkan secara seketika hasil dari agitasi via medsos ini.Medsos ini pula dinilai sarana tepat guna menguatkan opini si penyebar info, melakukan tukar-menukar data informatif, media penyebaran sebuah ide atau gagasan tertentu.

Saat ini medsos mampu menjadi alat yang akan menggiring lahirnya opini publik sehingga para $d a^{\prime} i$ (penceramah) ataupun para pendidik muslim tidak bisa menghindarkan dirinya dari alat komunikasi modern seperti medsos yang kita kenal ini. Sebenarnya hal ini menjadi nilai positif bagi mereka untuk melakukan medsos sebagai alat berdakwah yang mudah dengan tidak menghilangkan esensi dari dakwah tersebut. Dengan adanya medsos orang yang hendak berdakwah tidak lagi harus memikirkan waktu dan tempat yang akan menjadi alasan, asal bisa terhubung dengan jaringan internet, maka langsung bisa melakukan dakwah ke seluruh pelosok negeri. Akan tetapi jangan sampai hal ini menghilangkan tradisi dakwah secara tatap muka yang sudah dibangun selama ini sebagai ajang silaturahmi antar sesama umat muslim.

\section{Sejarah Perkembangan Media Sosial (Medsos)}

Penggunaan media sosial beberapa tahun terakhir ini meningkat pesat, hal itu dibuktikan dengan adanya perkembangan ilmu pengetahuan dan teknologi. Asosiasi Penyelenggara Jasa Internet Indonesia (APJII) mencatat pada tahun 2016 jumlah pengguna aktif media sosial di Indonesia sebanyak 129,2 juta atau sekitar 97,4\% dari keseluruhan pengguna internet di Indonesia. Survei APJII juga mencatat pelajar adalah pengguna dengan penetrasi tinggi $(69,8 \%)$.

Pada tahun 2014 ini data termutakhir menunjukkan pengguna internet dunia diperkirakan sudah melampaui 2,2 miliar atau sekitar 30 persen dari total populasi di dunia. Kemudian untuk pengguna Facebook, pada tahun 2012 baru mencapai 1 miliar dan pada tahun 2014 ini sudah mencapai 1,2 miliar pengguna. Sedangkan YouTube, pada tahun 2013 lalu rata-rata memiliki lebih dari 850 juta pengguna setiap bulannya. ${ }^{12}$ 
Data menarik disuguhkan oleh Statistik Pengguna Internet dan Mobile Indonesia. Pada tahun 2014 ini pengguna internet di Indonesia mencapai $15 \%$ atau 38,2 juta dari total jumlah penduduk sekitar 251,2 juta jiwa. Sedangkan pengguna medsos di Indonesia juga sekitar 15\% dari total jumlah penduduk Indonesia. Artinya, hampir seluruh pengguna internet memiliki akun medsos. Para pengguna medsos ini mengakses akun medsosnyaratarata sekitar 2 jam 54 menit dan sebanyak $74 \%$ mengakses akunnya melalui smartphone. ${ }^{13}$

Menurut penelitian Overdrive (ovrdrv.com), suatu lembaga riset pemasaran, jenis aplikasi medsos sedikitnya telah mencapai 240 aplikasi yang menawarkan ratusan cara berinteraksi. ${ }^{14}$ Tahun 2009 media sosial menjelma menjadi alat informasi yang sangat potensial di Indonesia. ${ }^{15}$ Media sosial beragam mulai bermunculan dan menjadi pilihan masyarakat, seperti facebook, twitter, instagram, path dan masih banyak lagi yang lainnya. ${ }^{16}$

Munculnya media jejaring sosial di dunia dimulai dengan munculnya Friendster pada tahun 2002 yang merupakan aplikasi untuk membangun relasi pertemanan dunia maya dengan cakupan yang luas yakni seluruh dunia. Setelah munculnya Friendster, media sosial yang selanjutnya adalah LinkedIn sebuah situs yang membagikan pengalaman mengenai dunia bisnis dan pekerjaan yang didirikan pada tahun yang sama. Selanjutnya pada tahun 2003 situs MySpace didirikan, berfokus pada orientasi musik sesorang, MySpace menjadi situs jejaring yang dapat digunakan untuk bertukarpesan/chatting, mengunggahlagu/video dan menyediakan layanan pemasangan genre musik khusus pada halaman profil. Pada tahun 2004 muncullah Flickr yakni situs yang memberi ruang penggunanya untuk mengunggah foto-foto dan video yang menarik dan dapat dibagikan kepada anggota di dalam situs tersebut.

Masih pada tahun yang sama, kemunculan Facebook sebagai media jejaring sosial yang memampukan kita untuk bertukar pesan pribadi maupun grup baik gambar maupun video, dalam Facebook kita juga 
dapat mengirimkan permintaan teman kepada seluruh pengguna situs tersebut di dunia. Setelah itu, pada tahun 2006 situs jejaring baru kembali muncul yakni Twitter. Situs tersebut merupakan jejaring sosial yang memampukan kita untuk mengikuti (follow) pengguna lain untuk dapat mengikuti postingan yang mereka buat. Situs ini juga memampukan kita untuk mengunggah gambar maupun video dan dapat mengirimkan pesan kepada pengguna lain.

Berselang 4 tahun, pada tahun 2010 Instagram muncul sebagai situs jejaring sosial yang memberi fasilitas untuk mengedit foto maupun video lalu mengunggahnya.Interaksi yang dibangun pada situs ini dapat berupa tombol suka (like), kolom komentar dan pengiriman pesan melalui Direct Message (DM).Line merupakan situs jejaring sosial selanjutnya yang muncul pada tahun 2011.Berbeda dengan situs jejaring sosial yang lain, line berfokus kepada penggunaan aplikasi untuk saling bertukar pesan. Sistem penambahan pertemanan di Line dapat ditemukan dengan menggunakan sistem add menggunakan username/ id. Namun pada situs ini, para pengguna juga diperkenankan untuk mengunggah foto maupun video di dalam timeline. Lalu pada tahun yang sama, Snapchat merupakan situs jejaring sosial yang memfasilitasi para pengguna untuk bertukar pesan dengan medium foto yang dapat diedit seperti memasukkan teks pesan dan menggunakan fitur efek pada foto.

Selanjutnya pada tahun 2011, Google+ merupakan situs dalam jaringan yang memiliki fitur-fitur di dalamnya yang dapat digunakan untuk berinteraksi.Seperti Google Hangout untuk bertukar pesan. Kemunculan Friendster pada tahun 2002 di Indonesia sempat menjadi situs jejaring sosial yang booming di kalangan remaja pada saat itu sempat memposisikan Indonesia sebagai pengguna Friendster paling banyak ke 3 di dunia. Friendster digunakan penggunanya untuk berkenalan via dunia maya dan sebagai sarana untuk bertukar pesan. Setelah itu Facebook muncul pada tahun 2004 namun pamor Facebook di Indonesia naik daun pada tahun 2008 dan mulai menggeser Friendster 
sebagai sarana berkenalan via dunia maya. Fitur-fitur yang ditawarkan oleh Facebook juga jauh lebih beragam seperti terdapat aplikasi games di dalamnya.

Pada tahun 2009 Twitter muncul sebagai situs jejaring sosial yang lebih simple dengan berfokus kepada penyajian timeline yang berisi status orang-orang yang kita ikuti disertai kolom komentar, kolom retweet/ like.Ide pencetusnya lahir dari seorang pemuda cerdas bernama Jack Dorsey. ${ }^{17}$ Situs ini juga dapat menjadi medium pertukaran pesan melalui Direct Message namun kita tidak bisa melihat pengguna yang online. Masih pada tahun yang sama, situs jejaring sosial berbasis aplikasi muncul yakni WhatsApp, namun pada tahun tersebut aplikasi ini belum dimintai banyak orang. Aplikasi ini berfokus pada pertukaran pesan antar individu maupun kelompok yang dapat melalui beberapa pilihan yakni teks, panggilan maupun video call.

Selanjutnya pada tahun 2010 Instagram menjadi situs jejaring sosial di Indonesia yang diminati.Situs ini berfokus pada aktualisasi diri melalui foto dan video yang dapat diedit. Interaksi pada situs ini dapat diwujudkan melalui tombol like, berkomentar pada kolom komentar maupun mengirimkan pesan kepada pengguna lain.

Line pada tahun 2011 adalah media sosial baru yang menggabungkan fitur aplikasi pesan singkat dengan media sosial sehingga berguna sebagai medium untuk bertukar pesan sehari-hari, situs jejaring sosial ini berfokus kepada pertukaran pesan baik kelompok maupun individu dengan individu lainnya. ${ }^{18}$ Selain pertukaran pesan, Line juga dilengkapi dengan fitur timeline dan beberapa fitur yang lain seperti games. Para pengguna dapat saling menambahkan teman dengan menggunakan fitur add friend.Snapchat juga muncul di Indonesia pada tahun yang sama yakni 2011, aplikasi ini diminati karena berbeda dengan aplikasi pertukaran pesan lainnya yang menggunakan teks, aplikasi ini berfokus kepada visual, baik foto maupun video yang disertai dengan efek-efek gambar, suara maupun teks yang dapat dimasukan di dalamnya. Para 
pengguna dapat menyebarkannya kepada khalayak publiknya yakni orang-orang yang mengikutinya atau mengirimnya secara pribadi kepada akun lainnya.

\section{Karakteristik dan Fungsi Media Sosial (Medsos)}

Kita dapat mengenali seseorang dari ciri-ciri atau karakter yang dimilikinya. Begitupun dengan media sosial dan kita dapat mengenalinya dengan melihat beberapa karakter yang dimilikinya, yaitu sebagai berikut: ${ }^{19}$

\section{a. Partisipasi Pengguna}

Semua media sosial mendorong penggunanya untuk berpartisipasi dan memberikan umpan balik terhadap suatu pesan atau konten di media sosial.Pesan yang dikirimkan dapat diterima atau dibaca oleh banyak orang.

\section{b. Adanya Keterbukaan}

Sebagian besar media sosial memberikan kesempatan bagi penggunanya untuk memberikan komentar, melakukan voting, berbagi, dan lain-lain.Pengiriman pesan dapat dilakukan dengan bebas tanpa harus melalui Gatekeeper.

\section{c. Adanya Perbincangan}

Kebanyakan media sosial memungkinkan adanya interaksi terhadap suatu konten, baik itu dalam bentuk reaksi ataupun perbincangan antar penggunanya.Dan penerima pesan bebas menentukan kapan melakukan interaksi terhadap pesan tersebut.

\section{d. Keterhubungan}

Melalui media sosial, para penggunanya dapat terhubung dengan pengguna lainnya melalui fasilitas tautan (links) dan sumber informasi lainnya. Proses pengiriman pesan ke media sosial yang lebih cepat dibandingkan dengan media lainnya membuat banyak informasi terhubung dalam satu media sosial. 
Selain itu ada beberapa ciri yang dimiliki dan melekat pada medsos, yaitu sebagai berikut: ${ }^{20}$

a. Konten yang disampaikan dibagikan kepada banyak orang dan tidak terbatas pada satu orang tertentu.

b. Isi pesan muncul tanpa melalui suatu gatekeeper dan tidak ada gerbang penghambat.

c. Isi pesan disampaikan secara online dan langsung.

d. Konten dapat diterima secara online dalam waktu lebih cepat dan bisa juga tertunda penerimaannya tergantung pada waktu interaksi yang ditentukan sendiri oleh pengguna.

e. Medsos menjadikan penggunanya sebagai kreator dan aktor yang memungkinkan dirinya untuk beraktualisasi diri.

f. Dalam konten medsos terdapat sejumlah aspek fungsional seperti identitas, percakapan (interaksi), berbagi (sharing), kehadiran (eksis), hubungan (relasi), reputasi (status) dan kelompok (group).

Secara umum, media sosial berbasis internet itu memiliki beberapa karakteristik, yaitu sebagai berikut: ${ }^{21}$

a. Mereka dapat digunakan secara acak.

b. Mereka dapat digunakan berdasarkan keinginan pengguna atau keinginan perancang atau pengembang sebagaimana direncanakannya.

c. Biasanya gagasan yang disajikan sesuai dengan simbol dan grafis.

d. Dapat melibatkan interaktivitas pengguna yang tinggi.

Selain itu media sosial mempunyai ciri-ciri, yaitu sebagai berikut:22

a. Pesan yang di sampaikan tidak hanya untuk satu orang saja namun bisa ke banyak orang contohnya pesan melalui SMS ataupun internet. 
b. Pesan yang di sampaikan bebas, tanpa harus melalui suatu Gatekeeper.

c. Pesan yang di sampaikan cenderung lebih cepat di banding media lainnya.

d. Penerima pesan yang menentukan waktu interaksi.

Kaplan dan Haenlein membagi media sosial menjadi lima bagian, yaitu sebagai berikut: ${ }^{23}$

a. Proyek Kolaborasi (wiki, bookmark).

b. Blog dan Mikroblog (twitter).

c. Konten (YouTube).

d. Situs jejaring sosial (facebook dan instagram).

e. Virtual Game Works (3D).

Menurut C. WidyoHermawan, adanya penggunaan internet melalui media sosial, telah menghadirkan sebuah web forum yang dapat membentuk suatu komunitas online. ${ }^{24}$ Interaksi yang dilakukan dalam media sosial haruslah komunikatif dan sopan. Sebagai manusia dalam kehidupan sehari-hari kita tidak akan pernah terlepas dari komunikasi. ${ }^{25}$

Disamping medsos mempunyai karakteristik yang melekat pada dirinya, medsos juga memiliki beberapa fungsi yang menyertainya, yaitu sebagai berikut: ${ }^{26}$

a. Sosial media adalah media yang didesain untuk memperluas interaksi sosial manusia menggunakan internet dan teknologi web.

b. Sosial media berhasil mentransformasikan praktik komunikasi searah, melalui media siaran dari satu institusi media ke banyak audience (one to many) menjadi praktik komunikasi dialogis antar banyak audience (many to many). 
c. Sosial media mendukung demokratisasi pengetahuan dan informasi.Mentransformasi manusia dari pengguna isi pesan menjadi pembuat pesan itu sendiri.

Hasil studi Jonah Berger dan Katherine Milkman (Struhar, 2014) menunjukkan bahwa berita-berita yang dibagikan secara viral melalui media sosial adalah berita yang mampu membangkitkan emosi positif atau negatif yang sangat kuat (high-arousal emotions). ${ }^{27}$

\section{Dampak Media Sosial (Medsos)}

Dampak medsos sangat berpengaruh terhadap perubahan perilaku manusia setelah diterpa pesan melalui media massa. Menurut Donald F. Robert Karena fokusnya pada pesan, maka dampak haruslah berkaitan dengan pesan yang disampaikan media massa tersebut. Dampak media juga diartikan sebagai dampak dari kehadiran sosial yang dimiliki media, yang menyebabkan perubahan pengetahuan, sikap dan tingkah laku manusia, akibat terpaan media. Semakin berkembangnya teknologi media massa dalam menyampaikan informasi dan hiburan, maka manusia tak akan pernah bisa lepas dari pengaruh media massa tersebut. Setiap hari, otak manusia selalu dipenuhi oleh informasi yang disampaikan..$^{28}$

Kebanyakan kasus yang terjadi dewasa ini mengenai efek atau dampak dari media adalah terhadap anak-anak yang sangat terpengaruh oleh media, terutama tontonan bagi mereka.Anak-anak hari ini sudah mulai meninggalkan dunianya yang notabene lebih kepada permainan tradisional. Permainan tradisional seperti, main gambar, main kelereng, main congklak, dan lain sebagainya sudah mulai ditinggalkan. Mereka lebih memilih untuk menonton YouTube, bermain facebook, dan bermain game online yang akan mempengaruhi perilakunya sehari-hari. Terlepas perubahannya ke arah yang lebih baik atau pun ke arah yang lebih buruk.

Secara aksiomatik, medsos sebagai salah satu fasilitas komunikasi modern yang dibutuhkan guna menanamkan berbagai nilai yang positif 
ke dalam tubuh masyarakat modern saat ini dengan mengetengahkan berbagai konten yang tepat guna untuk menanamkan sikap hidup manusia modern yang humanis dan bertanggungjawab.Sekalipun demikian, masih tersisa pertanyaan-pertanyaan seputar sejauh mana pengaruh medsos itu ke dalam pola fikir masyarakat modern saat ini. Semakin maju teknologi dalam masyarakat modern, maka semakin tinggi pula praktik bulshit dalam keseharian. ${ }^{29} \mathrm{Hal}$ ini juga melahirkan pertanyaan tentang langkah-langkah apakah yang harus dilakukan dalam menyebarkan misi moderasi beragama via medsos ini.

Kehadiran medsos membuat masyarakat berada dalam proses komunikasi yang tidak terpusat, tetapi menyebar. Tidak vertikal hirarkis lagi, melainkan lebih bersifat horizontal.Dalam kondisi demikian, proses komunikasi yang harus dikembangkan haruslah bersifat interaktif dialogis dengan membangun partisipasi publik alih-alih bersifat searah, komando dan paternalistik..$^{30}$ Dalam artian jangan sampai dengan adanya medsos membuat komunikasi seseorang memburuk, akan tetapi harus tetap terjalin dengan adanya komunikasi dua arah yang tetap memperhatikan lawan komunikasinya.

Berbagai situs jejaring sosial memudahkan pengguna untuk berbagi ide, saran, pandangan, aktivitas, informasi, acara, ajakan dan ketertarikan di dalam jaringan individu masing-masing.Selain layanan jejaring sosial bersifat terpusat pada individu, sosok atau tokoh, berkembang pula layanan komunitas yang sifatnya lebih terpusat pada grup atau kelompok bersama. $^{31}$

Dengan terus bermunculannya situs-situs medsos atau berbagai aplikasi medsos, secara garis besar medsos bisa dikatakan sebagai sebuah media online, di mana para penggunanya (user) melalui aplikasi berbasis internet tersebut dapat berbagi, berpartisipasi, dan menciptakan konten berupa blog, wiki, forum, jejaring sosial, dan ruang dunia virtual yang disokong oleh teknologi multimedia yang kian canggih. Internet, medsos dan teknologi multimedia menjadi satu kesatuan yang sulit dipisahkan 
serta mendorong pada hal-hal baru.Saat ini medsos yang paling banyak digunakan dan tumbuh pesat berupa jejaring sosial, blog dan wiki. ${ }^{32}$

Berikut ini ada beberapa kelebihan medsos modern saat ini dibandingkan media konvensional, yaitu sebagai berikut:

a. Cepat, ringkas, padatdansederhana.Kalaukitalihat, setiapproduksi media konvensional membutuhkan keterampilan khusus, standar yang baku dan kemampuan marketing yang unggul. Sebaliknya, medsos yang modern saat ini begitu mudah digunakan (user friendly), bahkan pengguna tanpa basis pengetahuan Teknologi Informasi (TI) pun dapat menggunakannya.Mereka hanya memerlukan komputer, tablet, smartphone, dan yang paling utama adalah adanya koneksi internet.

b. Menciptakan hubungan lebih intens.Media-media konvensional hanya melakukan komunikasi satu arah. Untuk mengatasi keterbatasan itu, media konvensional mencoba membangun hubungan dengan model interaksi atau koneksi secara live melalui telepon atau sms. Sedangkan medsos memberikan kesempatan yang lebih luas kepada user untuk berinteraksi dengan mitra, pelanggan, dan relasi, serta membangun hubungan timbal balik secara langsung dengan mereka.

c. Jangkauan luas dan global.Media-media konvensional memiliki daya jangkau secara global, tetapi untuk menopang itu perlu biaya besar dan membutuhkan waktu lebih lama. Sedangkan melalui medsos, siapa pun bisa mengkomunikasikan informasi secara cepat tanpa hambatan geografis. Pengguna medsos juga diberi peluang yang besar untuk mendesain konten, sesuai dengan target dan keinginan ke lebih banyak pengguna.

d. Kendali dan terukur.Dalam medsos dengan sistem tracking yang tersedia, pengguna dapat mengendalikan dan mengukur efektivitas informasi yang diberikan melalui respons balik serta 
reaksi yang muncul.Sedangkan pada media-media konvensional, masih membutuhkan waktu yang lama. ${ }^{33}$

Disamping manfaat, dengan adanya medsos juga terdapat beberapa madharat yang tidak kalah banyaknya. Dengan demikian, jangan hanya sebatas manfaat yang kita perhatikan, akan tetapi madharat pun harus kita perhatikan dan diantisipasi kehadirannya. Dengan adanya medsos banyak sekali berita bohong (hoax), ujaran kebencian, tontonan yang tidak senonoh, dan lain sebagainya yang merugikan masyarakat, terutama yang merusak generasi bangsa (anak-anak).

\section{Pengertian Moderasi}

Moderasi adalah suatu kebijakan yang membantu mengembangkan harmoni sosial yang membantu mengembangkan urusan pribadi, keluarga, dan masyarakat agar hubungan antara seseorang dengan orang lain bisa lebih luas. Terlepas dari keuntungan yang didapat, yang jelas sikap moderat sering diabaikan dalam kehidupan sehari-hari. Bukan hanya dalam kehidupan secara pribadi, tetapi terkadang moderat ini diabaikan dalam urusan keluarga, perlakuan terhadap lingkungan alam, praktik keagamaan, urusan keuangan dan juga hubungan sosial bermasyarakat lainnya.

Dalam bahasa agama, moderasi memiliki padananya yaitu wasatiyah. Wasathiyah adalah sikap hidup atau kerangka berfikir, bersikap dan berpola secara seimbang dalam segala dimensi kehidupan. Pada awalnya istilah Wasathiyah ini mula-mula dipopulerkan oleh Yusuf Al-Qardawy walaupun dengan tawadhu beliau menekankan bahwa beliau hanya mengelaborasi konsep Islam itu sendiri yang dilandasi sikap beragama seorang muslim, baik dalam urusan ibadat atau muamalat, dunia maupun akhirat.

Secara bahasa, kata wasath berarti sesuatu yang ada di tengah.Dalam Mufradat Al-fazh Al-Qur'anRaghib Al-Isfahani (entri w-s-th) menyebutkan secara bahasa bahwa kata wasath ini berarti, "Sesuatu yang memiliki dua belah ujung yang ukurannya sebanding."Kata ini juga bisa bermakna 
sesuatu yang terjaga, berharga, dan terpilih.Sebab, sesuatu yang ada di tengah-tengah tidak mudah untuk dijangkau secara langsung sehingga memungkinkannya untuk menjadi tempat menyimpan hal-hal yang berharga dan baik.Seperti kata "tengah kota". Kata ini menunjukkan tempat yang paling baik dan paling berharga dari suatu kota. ${ }^{34}$

Sementara itu, dalam makna wasath terdapat beberapa penjelasan. Fakhrudin Al-Razi menyebutkan ada beberapa makna yang satu sama lain saling berdekatan dan saling melengkapi.

Pertama, wasath berarti adil.Makna ini didasarkan pada ayat-ayat yang semakna, hadis nabi, dan beberapa penjelasan dari sya'ir Arab mengenai makna ini.Berdasarkan riwayat Al-Qaffal dari Al-Tsauri dari Abu Sa'id Al-Khudry dari Nabi Saw.bahwaummatanwasathan adalah umat yang adil.

Kedua, wasath berarti pilihan. Al-Razi memilih makna ini dibandingkan dengan makna-makna lainnya, karena beberapa alasan antara lain: kata ini secara bahasa paling dekat dengan makna wasath dan paling sesuai dengan ayat yang semakna dengannya yaitu QS. Ali Imran [3]: 110.

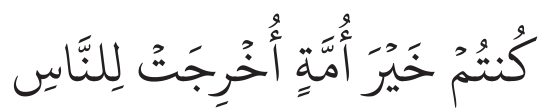

"Kalian adalah umat terbaik yang dilahirkan ke tengah manusia..." (QS Ali Imran [3]: 110).

Ketiga, wasath berarti yang paling baik.Keempat, wasath berarti orangorang yang dalam beragama berada di tengah-tengah antara ifrath (berlebih-lebihan hingga mengada-adakan yang baru dalam agama) dan tafrith (mengurang-ngurangi ajaran agama). ${ }^{35}$

Makna-makna di atas tidak bertentangan satu sama lain. Oleh sebab itu, Al-Sa'di menyimpulkan bahwa ummatwasath yang dimaksud adalah umat yang adil dan terpilih. Allah Swt., telah menjadikan umat ini pertengahan (wasath) dalam segala urusan agama (dibanding dengan agama-agama lain). Seperti dalam hal kenabian, syari'at, dan lainnya.Umat Islam ini adalah umat yang paling sempurna agamanya, 
paling baik akhlaknya, dan paling utama amalnya. Allah Swt., telah menganugerahi ilmu, kelembutan budi pekerti, keadilan, dan kebaikan (ihsan) yang tidak diberikan kepada umat lain. Oleh sebab itu, mereka menjadi "ummatanwasathan", umat yang sempurna dan adil agar "mereka menjadi saksi bagi seluruh manusia." ${ }^{36}$

Dari penjelasan para ahli tafsir mengenai makna wasath dalam ayat di atas dapat disimpulkan bahwa sifat wasath yang disematkan pada umat Muhammad Saw., adalah sesuatu yang melekat sejak umat ini menerima berbagai petunjuk dari Nabi-Nya.Ini merupakan karunia Allah Swt., kepada mereka.Saat mereka konsisten menjalankan ajaran-ajaran Allah Swt., maka saat itulah mereka menjadi umat terbaik dan terpilih. Oleh sebab itu, Rasyid Ridha mengaitkan kata ummatanwasathan ini dengan ayat sebelumnya, yaitu "...yahdi man yasya'uilashirath al-mustadaqim" (... Dialah yang akan memberi petunjuk kepada siapa saja yang dikehendakiNya menuju jalan yang lurus). Bila dikaitkan dengan ayat sebelumnya, maka umat terbaik, terpilih, dan moderat adalah mereka yang diberi petunjuk oleh Allah Swt., ke jalan yang lurus. ${ }^{37}$ Jalan yang lurus (sirath al-mustaqim) ini, sebagaimana dijelaskan dalam surat Al-Fatihah, adalah jalan tengah di antara jalan orang-orang yang dibenci (Yahudi) dan orang-orang yang sesat (Nashrani).

\section{Kerangka Literasi Media Sosial (Medsos) untuk Moderasi}

Hobbs (1996) mengatakan literasi media dapat dipahami sebagai proses dalam mengakses, menganalisis secara kritis pesan-pesan yang terdapat dalam media, kemudian menciptakan pesan menggunakan alat media. Pengetahuan tentang literasi media ibarat suntikan imunisasi dimana warga secara mandiri mampu menghasilkan antibodi yang siap menanggulangi berbagai potensi penyakit psikologis pada diri mereka akibat pengaruh konten buruk dari medsos. ${ }^{38}$

Untuk mewujudkan adanya literasi media, maka bisa dilakukan beberapa langkah berikut ini: Pertama, membangun perpustakaan yang lengkap via internet sehingga bisa menjadikan rujukan pemikiran, 
historis dan agamis dalam menyebarkan paham moderasi dan meredam radikalisme.Kedua, membentuk grup-grup diskusi di medsos guna menyebarkan paham wasatiyah secara massif.Ketiga, perlunya dibentuk mimbar para da'i dan cendekiawan sebagai pengganti mimbar secara fisik guna memuaskan kebutuhan intelektual melalui berbagi seminar dan workshop yang disebarkan melalui suara, gambar dan tulisan sehingga bisa dijangkau oleh publik guna memahami konsep Wasathiyah secara sempurna.Keempat, perlunya digelar dialog seputar konsep Wasathiyah ini melalui berbagai sarana visual dan audio-visual yang menggelorakan konsep wasatiyah ke kalangan publik.Kelima, menggiring publik untuk ikut serta dalam program edukasi Wasathiyah secara periodik dan sistematis.Keenam, perlunya dikembangkan program pendidikan dan pembelajaran sikap toleran dalam beragama dan menjauhi sikap ekstrem, terutama di kalangan anak muda. ${ }^{39}$

Termasuk sikap literasi adalah bahwa pengguna medsos harus konsisten mencari kebenaran bukan semata menyebarkan informasi tanpa mengetahui isi kebenaran beritanya.Banyak info medsos yang ujung-ujungnya adalah membuat kekacauan di kalangan kaum muslimin karena berhasil menyebarkan fitnah dan adu domba diantara mereka. ${ }^{40}$ Karenanya warganet dituntut meningkatkan keterampilan berpikir kritis (critical thingking skill) agar menjadi modal utama bagi mereka untuk menggiring beragam opini di medsos.Cogan \&Derricott (1998), menegaskan bahwa tantangan globalisasi pada abad 21 menuntut setiap warga negara memiliki karakteristik, salah satunya adalah kemampuan berfikir kritis dan sistematis. ${ }^{41}$

LiterasiMedsos terkait dengan sikap yang tepat dalam memposisikan penggunaan media sosial sebagai fenomena sosial yang membawa berbagai konsekuensi kehidupan, seperti ekonomi, sosial, politik dan juga sikap beragama sehingga mengarah kepada mediasi antara teknologi dengan khalayak untuk mempraktekkan teknologi secara tepat dan berbasis moralitas. ${ }^{42}$ Literasi ini juga terkait sikap seseorang yang mampu memilih, menetapkan, menggunakan, mengakses, mengelola dan 
mengevaluasi sebuah konten atu informasi sehingga mampu mengambil kesimpulan yang tepat, cepat dan cerdas, sehingga penggunaan medsos sangat tepat dan tidak salah guna. ${ }^{43}$

Dengan demikian perlu adanya kecerdasan dari seorang pengguna medsos(user) dalam menyikapi akan beberapa hal yang terjadi, sehingga tidak menimbulkan dampak buruk terhadap kehidupan sehari-hari. Disamping itu juga harus ada keseimbangan (balancing) yang diterapkan user medsos dalam menyikapi sesuatu, jangan sampai condong terhadap salah satu pihak. Akan tetapi apa yang terjadi dalam medsos harus dihadapi dengan sikap moderat atau seimbang.

Dakwah secara bijak diperlukan untuk mengerem atau membatasi segala sikap-sikap negatif yang akan mengotori misi suci Islam, termasuk bijak dalam menggunakan berbagai sarana yang ideal guna menyebarkan dakwah Islam. Karenanya para da'i Islam harus mampu menggunakan berbagai sarana komunikasi modern yang muncul pada zaman mutakhir ini guna menyampaikan saripati dakwah Islam secara massif dan sempurna.Juga melahirkan kesadaran memperkuat nial-nilai dan prinsip-prinsip Islam guna menjaga orisinalitas Islam dan wujud kohesifitas Umat secara utuh dan menyeluruh.

Pengguna medsos harus sangat arif dan bijaksana dalam menerima berbagai informasi, karena sejatinya sudah barang tentu tidak semua informasi baik dan layak untuk dikonsumsi secara publik.Ada beberapa informasi yang mereka (oknum) sebarkan hanya untuk menyesatkan dan mengelabui masyarakat.Contoh konkrit di atas, bahwa kaum radikalisme menggunakan jaringan internet melalui medsos dalam menjalan aksinya, yaitu dengan memberikan doktrin buruk terhadap masyarakat luas. Pengguna medsos harus hati-hati dan benar-benar waspada terhadap apa yang terjadi di medsos dan harus mempunyai sikap moderat atau adil dalam menerima berbagai informasi, terutama moderat dalam hal beragama (moderasi beragama). 
Dalam ranah praktis berteknologi, penyampai informasi juga dituntut untuk memiliki pengetahuan dan kemampuan etis sebagaimana dituntunkan al-Qur'an. Ini tercermin dalam berbagai tuntutan akhlakul karimah yang kontekstual dalam menggunakan media sosial, antara lain:

a. Menyampaikan informasi dengan benar, juga tidak merekayasa atau memanipulasi fakta (QS. al-Hajj: 30)

b. Bijaksana, memberi nasihat yang baik, serta argumentasi yang jelas, terstruktur dan baik pula (QS. an-Nahl: 125). Ini berarti bahwa karakter, pola-pikir, kadar pemahaman orang lain dalam jejaring pertemanan di media sosial umumnya beragam sehingga informasi yang disampaikan harus mudah dibaca dan dicerna, dengan tata bahasa yang baik pula.

c. Meneliti fakta.Untuk mencapai ketepatan data dan fakta sebagai bahan baku informasi yang akan disampaikan seorang muslim hendaknya mengecek dan meneliti kebenaran fakta dengan informasi awal yang ia peroleh agar tidakterjadi kadzib,ghibah, fitnah dan namimah (QS. al-Hujurat: 6). Ini artinya ketidak hatihatian dalam menyebutkan dan memberi informasi kepada pihak tertentu yang tersebar ke ranah publik bisa berakibat pencemaran nama baik sebagaimana larangan dalam UU ITE.

d. Tidak mengolok-olok, mencaci-maki, atau melakukan tindakan penghinaan sehingga menimbulkan kebencian (QS. al-Hujurat :11). Ini karena karakteristik dunia maya yang cair dan sangat bebas, memungkinkan melakukan tindakan-tindakan negatif kepada pihak lain sehingga memunculkan provokasi dan adu domba (flamming dan trolling).

e. Menghindari prasangka buruk atau suudzan (QS. al-Hujurat: 12).

Diambil baiknya medsos bisa dikatakan sebagai sarana untuk kebaikan, dan sekaligus sarana untuk beribadah. Kaidah ushul fikih berbunyi: li al-wasaaillhukm al-maqâshid, yakni suatu sarana mempunyai 
kedudukan hukum yang sama dengan suatu tujuan. Sarana yang dipergunakan untuk tujuan baik, hukumnya sama dengan tujuan baik itu sendiri. Bahkan dalam satu segi dan konteks tertentu, menggunakan medsos sebagai bagian dari kesempurnaan berdakwah adalah wajib. Sebagaimana kaidah fikih berbunyi: ma la yatimm al-wajib illa bihi fahuwawaajib. Maksudnya sesuatu yang menjadikan sempurnanya kewajiban maka iapun wajib.

Berdasarkan kerangka pikir inilah, kebutuhan dan pemanfaatan medsos adalah suatu kebutuhan bahkan keniscayaan di era modern, era informasi dewasa ini, dan merupakan bagian dari mencapai maqâshid al-Syari'ah (tujuan ajaran Islam), di antaranya hifz al-'aql, yakni perlindungan akal untuk mendapatkan informasi yang baik dan positif, dan menyampaikan informasi, gagasan, bahkan inovasi kepada masyarakat. Oleh karena itu, menggunakan medsos hendaknya dikelola dengan sebaik-baiknya, karena ia dapat menjadi ladang kebaikan yang dilipat gandakan.

Dalam pandangan Prof DadangKahmad, bahwa terdapat tiga hal yang perlu menjadi pegangan masyarakat millenial sebagai pengguna aktif media sosial.Tiga hal tersebut diantaranya adalah lakukanlah hal yang benar dan jelas, imbangilah perlakuan buruk dengan tindakan baik, bergaulah dengan manusia yang baik akhlaknya. ${ }^{44}$

Selain pendapat di atas, Majelis Ulama Indonesia (MUI) pun berpendapat bahwa ada beberapa kewajiban dan larangan seorang muslim yang harus ditunaikan dan dijauhi ketika menggunakan medsos, yaitu sebagai berikut:

\section{a. Kewajiban Muslim di medsos menurut MUI}

1) Senantiasa meningkatkan keimanan dan ketakwaan, tidak mendorong kekufuran dan kemaksiatan.

2) Mempererat persaudaraan (ukhuwwah), baik persaudaraan ke-Islaman(ukhuwah Islamiyyah), persaudaraan kebangsaan 
(ukhuwwahwathaniyyah), maupun persaudaraan kemanusiaan (ukhuwwahinsaniyyah).

3) Memperkokoh kerukunan, baik intern umat beragama, antar umat beragama, maupun antara umat beragama dengan pemerintah. ${ }^{45}$

\section{b. Larangan muslim di medsos menurut MUI}

1) Melakukan ghibah, fitnah, namimah, dan penyebaran permusuhan.

2) Melakukan bullying, ujaran kebencian dan permusuhan atas dasar suku, agama, ras atau antar golongan.

3) Menyebarkan hoax serta informasi bohong meskipun dengan tujuan baik, seperti info tentang kematian orang yang masih hidup.

4) Menyebarkan konten yang benar tetapi tidak sesuai tempat dan/atau waktunya. ${ }^{46}$

\section{Tantangan penyebaran konsep Wasathiyah via medsos}

Pertama, Konsep Wasathiyahdikesankan sebagai salah satu poros dalam konflik pemikiran dan filosofis sehingga dipandang sebagai poros ketiga, sehingga menjadi musuh bersama dari dua kelompok yang bersaing tersebut.Ini menjadi tantangan besar agar wasatiyahini dipandang bukan sesuatu yang baru namun sudah mengakar kuat dalam logika kemanusiaan dalam catatan sejarahnya. ${ }^{47}$

Kedua,memandangnegatifkonsepwasatiyahkarenadipandangsebagai bagian dari cara pandang Barat sehingga mempersepsikanwasatiyah sebagai bentuk kekalahan umat di hadapan hegemoni barat. Padahal sejatinya wasatiyah adalah bentuk perlawanan menuju perbaikan guna meraih kemenangan umat dalam berbagai dimensinya. ${ }^{48}$

Ketiga, para ekstremis menggelorakan kampanye radikalisme dalam balutan agama berupa fatwa-fatwa agama yang telah dipalsukan 
sehingga memiliki otoritas untuk dipercayai publik awam sebagai sebuah kebenaran nyata.

Keempat, hegemoni pemberitaan media massa konvensional yang selalu menggemborkan suasana lapangan kehidupan yang merosot di kalangan negara-negara Islam sehingga menghambat lahirnya optimisme dan berkembangnya sikap fatalisme sebagian umat sebagai bagian dari lahan subur berkembangnya radikalisme berbaju agama. ${ }^{49}$

Di akhir makalah ini setidaknya ada beberapa saran akademis, antara lain :

a. Konsep wasatiyah harus dibedakan dari aliran pemikiran maupun madzhab filsafat karena dipandang sebagai konsep hidup yang bukan sesuatu yang baru tetapi sudah tertanam sejak lama dalam warisan pemikiran umat dari masa ke masa.

b. Membentuk komite yang terdiri dari para pakar guna membentuk perpustakaan digital yang lengkap dalam memasyarakatkan konsep wasatiyah ini.

c. Menyusun berbagai serial kampanye terkait konsep wasatiyah dengan melakukan kerja sama dengan para ahli psikologi dan pendidikan serta para pakar medsos sehingga melahirkan konten edukasi yang sempurna dan menyenangkan.

d. Mendidik para pemuda untuk dilatih pandai berdebat secara pemikiran dengan pihak manapun dan memakai sarana medsos apapun.

Melakukan studi terkait dampak Medsos dalam menghadapi tantangan globalisasi sistem pendidikan di berbagai negara Islam. Juga dilakukan riset terkait dampak medsos bagi optimalisasi peran pendidikan dari berbagai lembaga kenegaraan maupun kemasyarakatan. 


\section{E. Kesimpulan}

Dari paparan di atas, dapat diambil kesimpulan bahwa literasi media sosial menjadi salah satu upaya yang penting dilaksanakan guna membantu masyarakat dalam memilah dan memilih setiap informasi yang mereka dapatkan diantara gencarnya informasi yang masuk, agar tidak terjebak ke dalam kubangan lumpur informasi yang kurang tepat di dunia maya.Masyarakat diharapkan memiliki daya fikir kritis serta pandai mengambil keputusan yang tepat dalam menyikapi penyebaran informasi di media sosial. Hal ini akan menyelamatkan masyarakat sebagai pengguna medsos dari terjebaknya sikap radikal dalam keberagamaan akibat provokasi informasi dari medsos. Sikap wasathiyyah ini mutlak dimasyarakatkan pula via medsos ketika para penggunanya sudah memiliki kemampuan meracik, memilih dan memilah konten informasi yang beredar selama ini. Masyarakat harus menguatkan alat filter informasi secara sistematis sehingga mampu mengelola dan mengatur setiap pola informasi yang masuk dan membiasakan diri untuk mengkroscek informasi yang baru didapatkan. Dengan demikian akanterciptalahliterasi media sosial yang menimbulkan sikap moderasi beragama di kalangan masyarakat, lautan informasi media sosial pun akan terkendalikan dengan baik melalui literasimedsos ini. 


\section{Daftar Pustaka}

Abduh, Muhammad. Tafsir Al-Manar. Dar al-Ma'arif: Beirut, t.t.

Agency, Beranda. Cara Bisnis di Internet. Gramedia: Jakarta, 2012

Alim, M. Yasir. MediatisasiAdama, Post Truth dan Ketahanan Sosial. LKiS Press: Yogyakarta, 2018

Al-Razi, Fakhruddin.Tafsir MafatihulGhaib. Dar al-Kutub al-Ilmiah: Beirut, t.t.

Al-Sa'di, Abdurahman.Taisir Al-Karim Al-Rahman fi Tafsir Kalam AlMannan.Al-Rayan Institution Publishers: Beirut, 2012

An-Naby, Abd.Wasail a-Ittisal al haditsahwadauruha fi ta'zizalWasathiyahwa al-itidal. al-Muantada Press: 2014

at-Tanaby, Abd. Wasail al-Ittisal al-haditsah, diambil dalam situs www. Wasatyea.net.

Azhar, Muhammad. Fikih Informasi. Diunduh dari website http://www. suaramuhammadiyah.id

C, Struhar. The Facebook Effect on the News.The Atlantic. 2014. Retrieved March 29, 2016, from www.theatlantic.com/business/ archive/2014/02/the-facebook-effect-on-thenews/283746

C. W., Hermawan. Cara Mudah Membuat Komunitas Online dengan PHPBB. ANDI: Yogyakarta, 2009

Darma. Buku Pintar Menguasai Internet. Jakarta: Mediakita, 2012

Fahmi, Abu Bakar. Mencerna Situs Jejaring Sosial.Elex Media Komputindo: Jakarta, 2011

Faiza, Arum, dkk. Arus Metamorfosa Milenial. Penerbit Ernest: Kendal Jawa Tengah, 2018 
Hisyam, M. Indonesia, Globalisasi dan Global Village. Obor Indonesia: Jakarta, 2017

http://fajar-kurnianto.blogspot.com/2015/05/media-sosial-danradikalisme.html

http://prezi.com/vddmcub_-ss_/social-media-definisi-fungsikarakteristik/

http://repository.iainbengkulu.ac.id/2759/1/DAMPAK\%20MEDIA \%20 SOSIAL\%20TERHADAP\%20PAHAM\%20RADIKALISME.pdf

http://www.umy.ac.id/perlu-ada-fiqh-media-sosial.html

http://www.wasatyea.net/ar/content

https://buanaindonesia.co.id/jabar/sudahkah-kita-berkarakter/

https://id.wikipedia.org/wiki/Efek_media

https://id.wikipedia.org/wiki/Media_sosial

https://sosmedkini.wordpress.com/pengertian-media-sosial/

https://www.aljamaa.net/ar

https://www.eramuslim.com/konsultasi/fikih-kontemporer/mainmedia-sosial-halal-atau-haram-ini-penjelasan-mui.htm/2\#. XaRwZ2bSLIU

https://www.eramuslim.com/konsultasi/fikih-kontemporer/mainmedia-sosial-halal-atau-haram-ini-penjelasan-mui.htm/2\#. XaRwZ2bSLIU

https://www.islam4u.com/ar/almojib

https://www.maxmanroe.com/vid/teknologi/internet/pengertian-mediasosial.html

https://www.qureta.com/next/post/medsos-menggulung-tata-nilaibangsa 
https://www.qureta.com/next/post/medsos-menggulung-tata-nilaibangsa

https://www.republika.co.id/berita/koran/opini-koran/15/03/16/nlarob4media-sosial-dan-radikalisasi

IbnKatsir, Al-Hafidz.Tafsir al-Qur'an al-Adzim. Dar al-Fikr: Beirut, t.t., Vol. 15

Ibnu Asyur, Muhammad At-Thahir. Al-Tahrir wa Al-Tanwir. Dar alSuhunun: Tunisia, 1997

Juju, Dominikus. Teknik Mempercepat Teknik Internet.Media Komputido: Jakarta, 2008

Kamali, M. Hasyim. The Middle Part of Moderation in Islam.Diuduh dari laman http://readingreligion.org/books/middle-path-moderationislam

Kaplan, Andreas M; Michael Haenlein. 2010. “Users of the world, unite! The challenges and opportunities of social media" . Business Horizons 53 : 59:68.

KBBI Online

Kemendag, Tim Humas. Panduan Optimalisasi Media Sosial.PHM Press: Jakarta, 2016

Kurnia, Novi. Literasi Digital keluarga.UGM Press: Yogyakarta: 2019

L, Safko\& Brake, D. K.The Social Media Bible. Hoboken. New Jersey: John Wiley \& Sons, 2009

Lutfi, Khabib. Masyarakat Indonesia dan tanggung jawab Moralitas. Guepedia Publisher: Jakarta, 2018

Manzhur, Ibnu. Lisanul Arab.Dar al-Fikr, Beirut: t.t.

Maryono, Y. Teknologi Informasi dan Komunikasi.Media Komputido: Jakarta, 2008 
Moleong, Lexy.Metode Penelitian Kualitatif. Remaja Rosdakarya, Bandung: 2011

Mulawarman dan AldilaDiyasNurfitri.Perilaku Pengguna Media Sosial beserta Implikasinya Ditinjau dari Perspektif Psikologi Sosial Terapan, Buletin Psikologi, 2014, Vol. V, No. 1

Nabila, Alif. Kumpulan Obrolan Mahasiswa IntarCimahi. Penerbit Harfeey: Yogyakarta, 2018

Nasrullah, Rulli. Teori Media Sosial (Perspektif Komunikasi, Kultur, dan SosisoTeknologi).SimbiosaRekatama Media: Yogjakarta, 2015

Nurhalimah, Siti, dkk. Media Sosial dan Masyarakat Pesisir.Depublisher: Jakarta, 2019

Nurudin.Media Sosial Baru.DPPMDIKTI: Yogyakarta: 2012

Ovrdrv.com/social-media-map

Sugiharti, Rahma. Budaya Populer dan Subkultur Anak Muda.Airlangga University Press: Surabaya, 2017

Yazid, Abu. Islam Akomodatif.LKiS: Yogyakarta, 2004

Zulfah, Siti. Pengaruh Perkembangna Teknologi Informasi Lingkungan (Studi Kasus Kelurahan Siti Rejo I Medan).Jurnal online ISSN: 2598-3814 dan cetak ISSN: 1410-4520 


\section{Endnotes}

1. Siti Nurhalimah, dkk. Media Sosial dan Masyarakat Pesisir.(Depublisher: Jakarta, 2019), h. 34

2. Siti Zulfah, Pengaruh Perkembangna Teknologi Informasi Lingkungan (Studi Kasus Kelurahan Siti Rejo I Medan).(Jurnal online ISSN: 2598-3814 dan cetak ISSN: 1410-4520).

3. M. Yasir Alim, MediatisasiAdama, Post Truth dan Ketahanan Sosial. (LKiS Press: Yogyakarta, 2018), h. 1-2

4. KhabibLutfi, Masyarakat Indonesia dan tanggung jawab Moralitas. (Guepedia Publisher: Jakarta, 2018), h. 6

5. Abu Yazid, Islam Akomodatif. (LKiS: Jogyakarta, 2004), h. 3

6. Ibid, h. 4

7. LexyMoleong, Metode Penelitian Kualitatif. (Remaja Rosdakarya, Bandung: 2011), h. 9

8. Mulawarman dan AldilaDiyasNurfitri, Perilaku Pengguna Media Sosial beserta Implikasinya Ditinjau dari Perspektif Psikologi Sosial Terapan, (Buletin Psikologi, 2014), Vol. V, No. 1, h. 37

9. https://id.wikipedia.org/wiki/Media_sosial

10. Arum Faiza, dkk.Arus Metamorfosa Milenial, h. 49-50

11. Kaplan, Andreas M; Michael Haenlein. 2010. “Users of the world, unite! The challenges and opportunities of social media" . Business Horizons 53 : 59:68.

12. Tim Humas Kemendag, Panduan Optimalisasi Media Sosial. (PHM Press: Jakarta, 2016), h. 29

13. Ibid, h. 42

14. Lihat ovrdrv.com/social-media-map

15. Abu Bakar Fahmi. Mencerna Situs Jejaring Sosial.(Elex Media Komputindo: Jakarta, 2011). 
16. Nurudin.Media Sosial Baru. (Yogyakarta: 2012 DPPMDIKTI).

17. Chupu Alay, Dinamika Internet, h. 67

18. M. Hisyam, Indonesia, Globalisasi dan Global Village. (Obor Indonesia: Jakarta, 2017), h. 476

19. https://www.maxmanroe.com/vid/teknologi/internet/pengertian-mediasosial.html

20. Tim Humas Kemendag, Panduan Optimalisasi Media Sosial, h. 27

21. M. Fadhilah, Panduan Menggunakan Media Sosial untuk Generasi Emas Milenial, h. 36

22. https://sosmedkini.wordpress.com/pengertian-media-sosial/

23. Ibid

24. Hermawan, C. W. Cara Mudah Membuat Komunitas Online dengan PHPBB. (ANDI: Yogyakarta, 2009)

25. RulliNasrullah. Teori Media Sosial (Perspektif Komunikasi, Kultur, dan SosisoTeknologi) (SimbiosaRekatama Media: Yogjakarta, 2015)

26. http://prezi.com/vddmcub_-ss_/social-media-definisi-fungsi-karakteristik/. diakses pada tanggal 28 Oktober 2019 pukul 14.20 WIB.

27. Struhar, C. The Facebook Effect on the News.The Atlantic. 2014. Retrieved March 29, 2016, from www.theatlantic.com/business/ archive/2014/02/thefacebook-effect-on-thenews/283746

28. https://id.wikipedia.org/wiki/Efek_media

29. M. Yasin ibid h. 77

30. Tim Humas Kemendag, Panduan Optimalisasi Media Sosial, h. 4

31. Ibid, h. 23

32. Ibid, h. 25

33. Ibid, h. 32

34. Muhammad At-Thahir Ibnu Asyur, Al-Tahrir wa Al-Tanwir, (Dar al-Suhunun, Tunisia: 1997), Jil. II h. 17 
35. Fakhruddin al-Razi, Tafsir MafatihulGhaib, Jil. II, h. 389-390

36. Abdurahman Al-Sa'di, Taisir Al-Karim Al-Rahman fi Tafsir Kalam AlMannan,Jil. I h. 70

37. Muhammad Abduh, Tafsir Al-Manar, Jil. II h. 4

38. https://www.qureta.com/next/post/medsos-menggulung-tata-nilai-bangsa

39. http://www.wasatyea.net/ar/content

40. https://www.aljamaa.net/ar

41. https://www.qureta.com/next/post/medsos-menggulung-tata-nilai-bangsa

42. Moh Faidhol. Communication and Information Beyond Boundaries, h. 33

43. ibid

44. http://www.umy.ac.id/perlu-ada-fiqh-media-sosial.html

45. https://www.eramuslim.com/konsultasi/fikih-kontemporer/main-mediasosial-halal-atau-haram-ini-penjelasan-mui.htm/2\#.XaRwZ2bSLIU

46. https://www.eramuslim.com/konsultasi/fikih-kontemporer/main-mediasosial-halal-atau-haram-ini-penjelasan-mui.htm/2\#.XaRwZ2bSLIU

47. Abd An-Naby, Wasail al -Ittisal al haditsahwadauruha fi ta'zizalwasatiyyahwa al-itidal, al-Muantada Press: 2014 h. 56

48. ibid

49. ibid 